\title{
Analisis Manajemen Laba, Penghindaran Pajak, Tata Kelola Terhadap Tanggung Jawab Sosial
}

\author{
Budi Harsono \\ Universitas Internasional Batam \\ budi.harsono@uib.ac.id

\section{Susanti \\ Universitas Internasional Batam \\ 1642045.susanti@uib.edu}

\begin{abstract}
This study focuses on explaining the correlation between earnings management, tax avoidance, and the mechanism of corporate governance of public listed companies on the Indonesia Stock Exchange (IDX). Disclosure of corporate social responsibility is the dependent variable tested, while the independent variables used include earnings management, tax avoidance, corporate governance and ownership structure. Company size and leverage are the control variables used in this test. This research was conducted using secondary data and panel regression methods. This study uses statistical programs such as SPSS and eviews. The research sample amounted to 2,160 data or equivalent to 432 companies listed on the Indonesia Stock Exchange in the 20142018 periods. The results of this study shows that the independent director variable, company size, leverage and foreign ownership had a significant effect, while earnings management, tax avoidance, managerial ownership, institutional ownership, the size of the board of directors and commissioners did not each have a significant effect on disclosure of corporate social responsibility.

Keywords corporate social responsibility, earnings management, tax avoidance, good corporate governance
\end{abstract}

\section{PENDAHULUAN}

Dalam menjalankan organisasi bisnis, setiap entitas mempunyai tanggung jawab pada pemangku kepentingan. Tanggung jawab tersebut dapat berasal dari pihak eksternal maupun internal. Pemangku kepentingan yang terlibat dalam suatu bisnis dapat berupa pemegang saham, karyawan, pemasok, pelanggan, komunitas serta lingkungan sekitarnya. Tanggung jawab yang dilakukan setiap entitas adalah tanggung jawab sosial dengan memandang seberapa tinggi tingkat kesadaran perusahaan dalam menentukan keputusan dari usahanya yang berdampak pada publik (Shafai, Amran \& Ganesan, 2018). Perkembangan praktek serta pengungkapan tanggung jawab sosial (CSR) di Indonesia bermula dengan adanya dukungan dari Pemerintah. Aktivitas tersebut tercermin dari dikeluarkan kebijakan terhadap kewajiban untuk melakukan praktek dan pengungkapan CSR melalui UU Perseroan Terbatas dengan No. 40 tahun 2007.

Permintaan akan CSR dari para pemangku kepentingan semakin meningkat. CSR juga sering dijadikan sebagai pembahasan dan diperdebatkan oleh para peneliti untuk peran dan keuntungannya, dengan beberapa isu ekonomi yang pernah terjadi seperti skandal Enron, krisis keuangan Asia pada tahun 1997 dan krisis AS. Oleh karena itu, 
sebagian besar perusahaan diberikan dorongan untuk lebih berkomitmen dalam menjalankan CSR (Villafuerte, 2015).

CSR dilakukan entitas bukan hanya sebatas dengan tujuan untuk memperoleh izin sosial dari masyarakat sekitar, melainkan agar operasional perusahaan dapat diterima serta meminimalkan kerugian lingkungan dari kegiatan operasionalnya. CSR dipercaya dapat menjadi salah satu kebijakan yang dapat meningkatkan kualitas hidup tersebut. Suatu entitas bukan hanya memiliki kewajiban ekonomis serta tanggung jawab terhadap para pemegang saham, tetapi memiliki tanggung jawab juga kepada pihak luar lainnya yang memiliki kepentingan terhadap perusahaan (Villafuerte, 2015). Pentingnya CSR ini dinilai, dimana sekarang ini berbagai praktek bisnis yang dilakukan perusahaan yang telah banyak merugikan masyarakat dan lingkungan disekitarnya. Contoh kerusakan lingkungan oleh praktek bisnis tersebut juga dapat dilihat dari salah perusahaan pertambangan terbesar di Indonesia yaitu Freeport.

Kebijakan praktek CSR dilakukan oleh seorang manajer perusahaan terkadang bertujuan hanya untuk menghindari kecurigaan dari para pemangku kepentingan. Praktek CSR memiliki kaitan antara kewajiban moral yang diberikan oleh suatu entitas terhadap lingkungan, kesehatan, pengelolaan sumber daya manusia, keselamatan karyawan pada lingkungan tempat kerja serta menjaga hubungan dengan para pemasok dan pelanggan. CSR sendiri kerap dijadikan sebagai alat yang digunakan oleh perusahaan dengan tujuan menutupi kelemahan manajemen. Manajemen perusahaan yang melakukan kegiatan tersebut bisa melakukan praktek CSR dengan menjaga lingkungan tempat perusahaan melakukan operasional dan kegiatan-kegiatan sosial, dengan tujuan membantu masyarakat sekitar. Dengan strategi yang dilakukan tersebut, manajer juga berharap untuk mengurangi resiko diberhentikan dari perusahaan bila proses kegiatan manajemen laba telah terbongkar (Cespa \& Cestone, 2007).

Terdapat berbagai pemahaman kita mengenai CSR dan juga aktivitas atau perilaku entitas. Pemahaman CSR yang paling dominan saat ini bahwa CSR adalah suatu kegiatan atau kebijakan yang sifatnya melebihi profit dan bukan hanya sekedar hubungan sosial terhadap masyarakat, tetapi CSR diharapkan dapat memberikan hal-hal yang bersifat positif terhadap masyarakat melebihi peraturan pemerintah terhadap CSR. Suatu perusahaan tidak mungkin membawakan kemakmuran bagi masyarakatnya tanpa mendatangkan keuntungan bagi perusahaannya. Dilihat dari sisi lain juga, ekonomi yang berkompetitif tinggi juga tidak bisa dihasilkan dari lahan sosial yang hampa (Villafuerte, 2015).

\section{LANDASAN TEORI}

Menurut Harsanti (2011) corporate social responsibility adalah suatu rancangan organisasi yang memperlihatkan kepedulian terhadap kepentingan masyarakat dengan mengambil suatu tanggung jawab dari dampak kegiatan operasional perusahaan tersebut. Konsep CSR perusahaan pertama kali diperkenalkan pada 1990-an oleh perusahaan multinasional, tetapi tidak ada perhatian yang diberikan pada waktu itu. Bencana lingkungan dan pemanasan global telah meningkatkan kesadaran tanggung jawab lingkungan perusahaan. Oleh sebab itu, perusahaan mengambil kewajiban sebanyak mungkin terhadap masalah lingkungan dan mencerminkan harapan serta keprihatinan sosial yang berkembang (Juhmani, 2014).

Pengungkapan CSR ini penting untuk memberikan informasi kinerja lingkungan dan mempengaruhi pasar modal. Oleh karena itu, investor korporat dan pemangku kepentingan lainnya perlu menggunakan informasi lingkungan dalam pengambilan 
keputusan mereka. Dalam menanggapi kekhawatiran investor dan pemangku kepentingan lain tentang kebijakan lingkungan perusahaan, banyak perusahaan secara sukarela meningkatkan tingkat pengungkapan sosial dan lingkungan mereka melalui berbagai sumber dan media. Namun, media yang paling terkenal dan banyak digunakan adalah laporan dan situs web tahunan (Villiers \& Staden, 2011).

Suatu entitas cenderung melaporkan berita yang lebih positif dalam memproyeksikan perilaku etis, meskipun melaporkan keseimbangan perhatian pada berita baik dan buruk terhadap informasi yang bermanfaat bagi kredibilitas pelaporan CSR. Suatu perusahaan yang secara selektif mengungkapkan berita baik sambil mempertahankan berita buruk yang dapat menciptakan kesan positif yang menyesatkan tentang kinerja lingkungan yang sebenarnya, dikenal dengan greenwasher (Delmas \& Burbano, 2011).

Teori tentang program pengungkapan CSR sudah banyak dikembangkan oleh peneliti-peneliti sebelumnya seperti: ISO 26000, program PROPER, program GRI dan juga program penilaian pengelolaan lingkungan hidup. ISO 26000 merupakan program CSR yang paling sering digunakan sebagai indikator pengungkapan CSR saat ini, disamping itu ISO 26000 juga merupakan salah satu indikator yang telah disetujui sebagai pengungkapan CSR di Indonesia (Jalal, 2010).

Aspek kunci dari ISO 26000 adalah menetapkan prinsip-prinsip panduan yang bertentangan dengan spesifikasi untuk sertifikasi. Dengan demikian tidak ada organisasi yang akan menjadi ISO 26000 bersertifikat, seperti halnya dengan standar lain. Dengan kata lain tujuan ISO 26000 bukan untuk mendefinisikan sistem melalui serangkaian persyaratan. ISO 26000 hanya mengembangkan bentuk-bentuk praktis tanggung jawab sosial, dirancang untuk mendukung organisasi yang berkontribusi pada pembangunan berkelanjutan (Juhmani, 2014).

Menurut Smith (2011), Organisasi Standar Internasional (ISO) telah menciptakan organisasi internasional standar untuk tanggung jawab sosial sektor swasta (perusahaan) dan publik organisasi. ISO 26000 menetapkan tujuh subjek inti tanggung jawab sosial, yang semuanya adalah bagian dari definisi CSR terkini yaitu:

1. Tata kelola organisasi;

2. Hak asasi Manusia;

3. Praktek Ketenagakerjaan;

4. Lingkungan;

5. Praktek Kegiatan Institusi yang Sehat;

6. Konsumen; dan

7. Pengembangan Masyarakat.

Tujuh subjek inti ini pada dasarnya adalah heuristik untuk diikuti oleh perusahaan, yang dapat bermanfaat bagi perusahaan dalam membuat program di sekitar area yang menurut ISO harus diwakili oleh CSR. Praktek ini konsisten dengan standar ISO lainnya untuk membantu perusahaan dengan meningkatkan proses dan mengimplementasikan program kepatuhan. Tujuh subjek inti memiliki fokus besar pada manajemen pemangku kepentingan dan perilaku etis. Standar ini dapat memberikan beberapa panduan yang berguna dan dapat dimanfaatkan oleh perusahaan (GRI, 2002).

GRI (Global Reporting Intiative) dijadikan sebagai salah pedoman dalam pengungkapan CSR. Dalam pengungkapan GRI ini indikator yang dipakai dalam pengungkapan CSR meliputi tata kelola organisasi, pengungkapan strategi, profil organisasi dan juga manajemen kinerja. Indikator yang dicantumkan pada pedoman GRI (GRI, 2002), yakni: 
1. Indikator Kinerja Sosial yang terdiri dari 40 item pengungkapan.

2. Indikator Kinerja Lingkungan meliputi 30 indikator pengungkapan; dan

3. Indikator Kinerja Ekonomi terdapat 9 indikator pengungkapan;

\section{A. Manajemen Laba}

Manajemen laba merupakan intervensi yang dilakukan manajemen perusahaan saat proses pelaporan keuangan eksternal, bertujuan demi salah satu keuntungan pribadi.(Schipper, 1989). Praktik manajemen laba akan terjadi ketika manajer mengeluarkan kebijakan manajerial dalam pelaporan pendapatan dengan mengubah informasi keuangan (Leuz \& Christian, 2017). Terdapat korelasi manajemen laba dan CSR membuktikan bahwa manajer turut terlibat dalam perilaku diskresi ini, cenderung terlibat dalam kegiatan CSR yang lebih banyak.

Penelitian Surroca dan Tribo (2008) menunjukkan korelasi positif antara manajemen laba dengan CSR, dan berpendapat bahwa CSR dapat digunakan untuk mengumpulkan dukungan serta perlindungan dari pemangku kepentingan. Demikian pula, Pagano dan Volpin (2005), Gargouri, Hajjem, Gingras dan Brody (2010), Jo Hoje dan Harjoto (2011), Desai dan Dharmapala (2012), Scholtens dan Kang (2013), Muttakin dan Subramaniam (2015) menyatakan bahwa tingkat kinerja CSR yang berkaitan dengan lingkungan dan dimensi karyawan secara positif terkait dengan manajemen laba.

Chih, Shen dan Kang (2008), Prior et al. (2008), Kim (2012), Cho dan Chun (2016), Christensen (2016), Djuitaningsih dan Marsyah (2016), Gras-Gil, Manzano dan Fernandez (2016), Martinez-Ferrero dan Frias-Aceituno, (2016), Alsaadi, Madison, Hodson dan Langlois (2017), Garcia-Sanchez dan Garcia-Meca (2017) melakukan penelitian terhadap CSR dan berdasarkan hasil empiris, menyatakan manajemen laba sendiri berkorelasi negatif terhadap CSR disclosure. Penelitian diatas tidak sejalan dengan Prior, Surroca dan Tribo (2008) yang menemukan adanya hubungan positif, sedangkan Sukarmi (2008), Kim (2012), Terzaghi (2012), Salewski dan Zulch (2014), Tumewu dan Rudiawarni (2014) tidak menemukan adanya korelasi yang signifikan antara kedua variabel tersebut.

\section{$H_{1}$ : Manajemen laba berpengaruh signifikan positif terhadap pengungkapan CSR.}

\section{B. Penghindaran Pajak}

Menurut Hanlon dan Heitzman (2010), penghindaran pajak diartikan sebagai pengurangan pajak sebenarnya dan mencakup berbagai strategi pajak. Penghindaran pajak dianggap sebagai peningkatan nilai bagi pemegang saham. Para manajer juga didorong untuk mempraktikkan upaya terbaik mereka dalam memaksimalkan kekayaan pemegang saham dengan meminimalkan pajak (Christensen \& Murphy, 2004).

Octaviana dan Rohman (2014) melakukan penelitian dengan menunjukkan hasil bahwa semakin rendah penghindaran pajak maka pengungkapan CSR semakin tinggi. Schon (2008), Watson (2011), Huseynov dan Klamm (2012), Davis (2013), Lanis dan Richardson (2013), Zhang (2013), Oktaviana (2014), Utari (2014), Elbaz (2015), Dharma dan Noviari (2017) menunjukkan hasil penelitian bahwa entitas yang tidak banyak melakukan praktik penghindaran pajak sebagai bentuk tindakan bertanggung jawab secara sosial, akan melakukan aktivitas CSR lebih tinggi. Hasil penelitian tersebut, tidak konsisten dengan penelitian Hansen (2015), Villafuerte (2015).

$\mathrm{H}_{2}$ : Penghindaran pajak berpengaruh signifikan positif terhadap pengungkapan CSR. 


\section{Kepemilikan Manajerial}

Persentase saham dipegang oleh manajemen yang secara aktif berpartisipasi mengambil suatu kebijakan termasuk para komisaris dan direktur perusahaan dapat diartikan sebagai kepemilikan manajerial. Pemegang saham manajerial sangat memungkinkan manajer yang akan mendominasi perusahaan dan menjadi penentu keputusan kebijakan serta strategi mana yang akan diambil perusahaan (Khan dan Muttakin, 2013).

Gray (1988), Sembiring (2005), Rosmasita (2007), Oliveira dan Ferreira (2011), Dewi (2013), Eriandani (2013), Udayana (2013), Paramita dan Marsono (2014), Prakasa (2016), Rahayu (2016) serta Masyitah (2016) melakukan penelitian kepemilikan manajerial terhadap CSR disclosure dan mendapatkan hasil yang positif. Sedangkan hasil penelitian Huafang dan Jinguo (2007), Rustiarini (2008), Said (2009), Mulia (2010), Waryanto (2010), Badjuri (2011), Tamba (2011), Nur dan Priantinah (2012), Terzhagi (2012), Laksmitaningrum dan Purwanto (2013), Martua dan Nasir (2013), Djuitaningsih dan Marsyah (2016), Swandari (2016), Saputro (2019) yang menemukan bahwa kepemilikan manajerial tidak berpengaruh terhadap CSR disclosure.

\section{$\mathrm{H}_{3}$ : Kepemilikan manajerial berpengaruh signifikan positif terhadap pengungkapan CSR.}

\section{Kepemilikan Institusional}

Kepemilikan institusional biasanya merupakan pemegang saham terbesar dalam suatu entitas. Saham tersebut dimiliki lembaga institusi yaitu bank, perseroan terbatas, perusahaan investasi, serta institusi-institusi lain. Investor institusional dapat memonitor manajemen perusahaan (Laksmitaningrum \& Purwanto, 2013). Pemegang saham institusi yang besar pada suatu entitas, akan melakukan kegiatan CSR dan melaporkannya pada laporan tahunan guna meningkatkan nama baik perusahaan dan nilai perusahaan. Keterlibatan entitas terhadap aktivitas CSR tersebut, nantinya akan memberikan manfaat jangka panjang kepada pemegang saham institusi (Fauzi, Mahoney \& Rahman, 2007).

Penelitian Fauzi et al. (2007), Mahoney (2007), Rahman (2007), Machmud dan Djaman (2008), Utami dan Rahmawati (2010), Nilasari (2011), Rahkmawati (2011), Eriandani (2013), Saraswati dan Hadiprajitno (2013), Tumewu dan Rudiawarni (2014), Djuitaningsih dan Marsyah (2016) tentang korelasi kepemilikan institusional terhadap CSR mendapatkan hasil yang tidak signifikan, akan tetapi Anggraini (2006), Nofandrilla (2008), Saleh (2010), Yulia dan Paramitha (2011), Sari (2013), Sukoharsono (2013), Sutrisno (2013), Soliman (2013), Udayana (2013), Saputro (2019) menarik kesimpulan yang berbeda yaitu adanya hubungan kepemilikan institusional dalam CSR disclosure.

\section{H4 : Kepemilikan institusional berpengaruh signifikan positif terhadap pengungkapan CSR.}

\section{E. Kepemilikan Asing}

Kepemilikan asing dinyatakan berdasarkan persentase pemegang saham di perusahaan Indonesia yang dimiliki oleh individu ataupun lembaga asing. Melakukan investasi di negara lain pastinya memiliki risiko bisnis lebih tinggi dikarenakan sosial, lingkungan, budaya dan juga ekonomi yang berbeda serta perbedaan informasi yang diberikan oleh pihak lain (Cahyani \& Suryaningsih, 2016). Pengungkapan CSR umumnya lebih tinggi ketika adanya kepemilikan asing, dikarenakan adanya pemisahan antara pemilik dan manajemen secara geografis, serta kebanyakan pemilik asing memiliki proporsi saham yang lebih besar (Bradbury, 1991). 
Kepemilikan asing memiliki korelasi positif terhadap CSR disclosure pada penelitian yang dilakukan oleh Chang (2003), Chapple dan Moon (2005), Tanimoto dan Suzuki (2005), Kim (2007), Darus (2009), Puspitasari (2009), Said (2009), Saleh (2010), Oh (2011), Tamba (2011), Khan dan Muttakin (2013), Soliman (2013), Sufian dan Zahan (2013), Sissandhy (2014), Dewi (2015), Isa dan Muhammad (2015), dimana dorongan CSR disclosure akan meningkat saat perusahaan memiliki kepemilikan asing yang besar. Penelitian Marwata (2006), Djakman (2008), Machmud (2008), Anggraini (2010), Diba (2012), Amelia (2013) bertentangan dengan beberapa peneliti diatas yang menyatakan bahwa tidak adanya korelasi signifikan terhadap CSR disclosure di Indonesia.

\section{$H_{5}$ : Kepemilikan asing berpengaruh signifikan positif terhadap pengungkapan} CSR.

\section{F. Ukuran Dewan Direksi}

Teori agensi mengklaim bahwa ukuran dewan direksi yang besar akan membantu mengurangi biaya agensi dengan melaksanakan kegiatan yang lebih bertanggung jawab secara sosial, terutama pada saat krisis dan perubahan peraturan. Oleh karena itu, dewan direksi merupakan komponen penting dari mekanisme tata kelola perusahaan untuk mengatur operasi bisnis secara adil dan dengan cara yang tepat. Konsisten dengan teori pemangku kepentingan, keputusan dewan yang berkaitan dengan praktik pengungkapan CSR harus menyeimbangkan kepentingan semua pemangku kepentingan (Said, 2009). Representasi di dewan dapat memberikan masukan bermanfaat bagi pemangku kepentingan terhadap keputusan di tingkat dewan dan membantu dewan merespon lebih baik terhadap ketergantungan sumber daya yang dihadapi perusahaan. Karena pemangku kepentingan biasanya meminta transparansi yang lebih besar, perwakilan mereka yang lebih luas cenderung memiliki efek positif pada kebijakan pengungkapan CSR. Semakin besarnya jumlah dari dewan direksi, maka kemampuan perusahaan dapat melaksanakan CSR juga semakin tinggi (Ali \& Atan, 2013).

Prastiwi (2011), Suryono (2011), Esa dan Ghazali (2012), Pebriana (2012), Ali dan Atan (2013), Abdelkader (2016) melakukan penelitian ukuran direksi terhadap CSR disclosure dan mendapatkan korelasi positif antar kedua variabel. Sedangkan Intan (2016) dan Sadou (2017) menarik kesimpulan yang menunjukkan ukuran direksi tidak berkolerasi signifikan terhadap CSR disclosure di Indonesia.

\section{$\mathrm{H}_{6}$ : Ukuran dewan direksi berpengaruh signifikan positif terhadap pengungkapan} CSR.

\section{G. Direktur Independen}

Menurut MCCG 2012, direktur independen dapat diartikan sebagai seorang yang tidak mempunyai kaitan dengan perusahaan, baik itu merupakan anak perusahaan terkait, atau perusahaan induk dan memiliki setidaknya 10 persen kepemilikan saham. Kehadiran direksi independen pada dewan direksi dianggap sebagai pantauan cara kerja atau bagaimana suatu perusahaan beroperasional terhadap tata kelola perusahaan. Secara umum diyakini bahwa direktur luar yang independen dapat mendorong dewan menjadi lebih diperkuat dengan selalu mengawasi kegiatan manajemen dan berupaya menjaga kepentingan semua investor agar terlindungi (Petra, 2005).

Sebuah riset yang dilakukan oleh Harjoto dan Jo (2011) melaporkan dewan independensi berkorelasi terhadap pengungkapan CSR. Rouf (2010), Arfiur (2012), Muttakin dan Subramaniam (2015), Dias et al. (2017), Naseem (2017), Sadou (2017) memiliki pandangan sejalan dengan penelitian sebelumnya bahwa direktur independen berkorelasi positif terhadap CSR disclosure. Namun penelitian Rahman dan Widyasari 
(2008), Saravanan (2009), Martin (2012), Rahman dan Ismail (2016) bertentangan dengan para peneliti sebelumnya yang menunjukan bahwa direktur independen tidak berkorelasi terhadap CSR disclosure. Dengan uraian diatas, terdapat konsistensi yang belum jelas mengenai hubungan direktur independen terhadap CSR.

$\mathrm{H}_{7}$ : Direktur independen berpengaruh signifikan positif terhadap pengungkapan CSR .

\section{H. Dewan Komisaris}

Dewan komisaris berfungsi untuk membantu memantau manajemen perusahaan yang dipegang oleh para dewan direksi serta membantu menentukan bahwa manajemen perusahaan telah benar menjalankan tugas dalam pengembangan perusahaan dan melakukan kontrol internal di dalam perusahaan (Nur \& Priantinah, 2012). Anggota dewan komisaris yang besar juga akan meningkatkan kesempatan untuk mengendalikan direksi dan meningkatkan kemudahan dalam pengawasan perusahaan serta direksi. (Coller \& Gregory, 2005).

Penelitian sebelumnya yang dilakukan oleh Coller dan Gregory (1999), Muntoro (2006), Sembiring (2005), Sulastini (2007), Andayani (2008), Sitepu dan Siregar (2008), Dewi (2013), Amalia (2013), Laksmitaningrum dan Purwanto (2013) menunjukkan hasil bahwa ukuran dewan komisaris mempunyai pengaruh signifikan terhadap CSR disclosure. Sedangkan Ahmad (2003), Matoussi (2008), Chakroun (2008), Handajani (2009), Said (2009), Fahrizqi (2010), Waryanto (2010), Effendi (2012), Udayana (2013), Komalasari (2014), Sari (2014), Djuitaningsih dan Marsyah (2016) menyatakan bahwa tidak adanya pengaruh antara kedua variabel tersebut. Dari uraian diatas, bahwa masih kurangnya konsistensi yang jelas antar peneliti.

\section{Hs : Ukuran dewan komisaris berpengaruh signifikan positif terhadap pengungkapan CSR.}

\section{METODOLOGI PENELITIAN}

Dalam penelitian ini, variabel bebas yang dipilih meliputi: manajemen laba, penghindaran pajak, struktur kepemilikan dan tata kelola perusahaan. Ukuran perusahaan dan leverage digunakan sebagai variabel kontrol, untuk variabel terikat yang digunakan adalah pengungkapan CSR yang menggunakan proksi indeks CSR berbasis ISO 26000.

Pengumpulan data penelitian ini didapatkan dari sumber data sekunder dan metode waktu pengumpulan data time series. Perusahaan publik yang terdaftar di Indonesia mulai dari tahun 2014 sampai dengan 2018 sebagai objek penelitian. Untuk mendukung penelitian ini, data yang didapatkan menggunakan metode purposive sampling, dimana sampel didapatkan tanpa dipilih dengan acak tetapi berlandaskan pada beberapa kriteria penelitian telah ditentukan oleh peneliti (Indiantoro dan Supomo, 2013).

Kriteria dalam pemilihan sampel dan telah ditentukan oleh peneliti sebagai berikut:

1. Merupakan instansi di Indonesia dan telah terdaftar di BEI;

2. Memiliki laporan keuangan yang sudah terdaftar di BEI yang dimulai dari tahun 2014 hingga 2018 dan;

3. Laporan tahunan yang telah dipublikasikan harus memiliki kumpulan data yang dibutuhkan dalam perhitungan variabel yang diteliti yaitu manajemen laba, penghindaran pajak, struktur kepemilikan, tata kelola perusahaan, ukuran perusahaan, leverage serta pengungkapan CSR.

Berikut merupakan pengukuran daripada masing-masing variabel: 
Tabel 1 : Definisi Variabel Operasional

\begin{tabular}{|c|c|c|c|}
\hline Jenis Variabel & Nama Variabel & Pengukuran Variabel & Referensi \\
\hline Dependen & Pengungkapan CSR & $\begin{array}{l}37 \text { jenis Indeks CSR berdasarkan } \\
\text { ISO } 26000\end{array}$ & $\begin{array}{l}\text { Muttakin dan } \\
\text { Subramaniam } \\
(2015)\end{array}$ \\
\hline \multirow{8}{*}{ Independen } & Manajemen Laba & Total accrual & $\begin{array}{l}\text { Choi dan Park } \\
(2013)\end{array}$ \\
\hline & Penghindaran pajak & $\begin{array}{l}\text { ETR = Biaya pajak penghasilan } \\
\text { saat ini dibagi pendapatan } \\
\text { sebelum pajak }\end{array}$ & $\begin{array}{lll}\text { Shafai } & \text { et } & \text { al. } \\
(2018) & & \end{array}$ \\
\hline & Kepemilikan Manajerial & $\begin{array}{l}\text { Komposisi saham yang dimiliki } \\
\text { oleh manajerial dari jumlah } \\
\text { saham yang beredar }\end{array}$ & $\begin{array}{lll}\text { Shafai } & \text { et } & \text { al. } \\
(2018) & & \end{array}$ \\
\hline & Kepemilikan Institusional & $\begin{array}{l}\text { Komposisi saham yang dimiliki } \\
\text { oleh institusi dari jumlah saham } \\
\text { yang beredar }\end{array}$ & $\begin{array}{l}\text { Tita dan Marsyah } \\
\text { (2012) }\end{array}$ \\
\hline & Kepemilikan Asing & $\begin{array}{l}\text { Komposisi saham yang dimiliki } \\
\text { oleh investor asing dari jumlah } \\
\text { saham yang beredar }\end{array}$ & Etha (2010) \\
\hline & Ukuran Dewan Direksi & $\begin{array}{l}\text { Jumlah dewan direksi dalam } \\
\text { perusahaan }\end{array}$ & Said (2009) \\
\hline & Direktur Independen & $\begin{array}{lrr}\text { Komposisi } & \text { anggota } & \text { dewan } \\
\text { independen } & \text { terhadap } & \text { jumlah } \\
\text { dewan direksi } & & \\
\end{array}$ & $\begin{array}{l}\text { Dias Rodrigues } \\
\text { dan Craig (2017) }\end{array}$ \\
\hline & Ukuran Dewan Komisaris & $\begin{array}{ll}\text { Jumlah komisaris } & \text { dalam } \\
\text { perusahaan } & \end{array}$ & Esa et al. (2012) \\
\hline \multirow[t]{2}{*}{ Kontrol } & Ukuran Perusahaan & Logaritma dari jumlah aset & Esa et al. (2012) \\
\hline & Leverage & $\begin{array}{l}\text { Jumlah liabilitas terhadap jumlah } \\
\text { aset }\end{array}$ & $\begin{array}{l}\text { Irham } \\
(2013)\end{array}$ \\
\hline
\end{tabular}

Metode yang digunakan pada pengujian hipotesis penelitian ini adalah metode analisis regresi panel. SPSS dan Eviews 10 merupakan program analisa data yang akan digunakan untuk menganalisis data pada penelitian ini.

\section{HASIL PENELITIAN}

Keseluruhan instansi yang ada di Indonesia dan sudah terdaftar di BEI sebanyak 649 instansi, terdapat 200 instansi yang tidak memiliki data yang cukup lengkap untuk penelitian serta terdapat 76 jumlah data outlier. Sebanyak 432 perusahaan yang dipilih sebagai sampel penelitian dengan menggunakan data observasi perusahaan berturut-turut selama 5 tahun. Total data observasi yang didapatkan sebesar 2.084 data. Untuk hasil statistik bisa dilihat pada gambar tabel dibawah ini:

Tabel 2 : Hasil Uji Analisis Statistik Deskriptif pada Variabel Berskala Rasio

\begin{tabular}{|l|r|r|r|r|r|}
\hline \multicolumn{1}{|c|}{ Variabel } & \multicolumn{1}{c|}{ N } & \multicolumn{1}{c|}{ Minimum } & \multicolumn{1}{l|}{ Maximum } & \multicolumn{1}{c|}{ Mean } & \multicolumn{1}{l|}{ Std Deviation } \\
\hline CSR & 2084 & .027027 & .918919 & .38548529 & .183170242 \\
\hline DACC & 2084 & -.893539 & 5.092217 & .12975731 & .267869391 \\
\hline ETR & 2084 & -43.983634 & 21.575401 & -.21963672 & .788868082 \\
\hline MO & 2084 & .000000 & .956061 & .03739448 & .118803501 \\
\hline IO & 2084 & .000000 & .999974 & .63483465 & .255481673 \\
\hline FO & 2084 & .000000 & .997700 & .23603615 & .300306161 \\
\hline BS & 2084 & 2 & 15 & 4.89 & 2.091 \\
\hline BI & 2084 & .000000 & .666667 & .17043086 & .146033226 \\
\hline
\end{tabular}




\section{JESYA}

JURNAL EKONOMI \& EKONOMI SYARIAH

Jurnal Ekonomi \& Ekonomi Syariah Vol 5 No 1, Januari 2022

E-ISSN : 2599-3410 | P-ISSN : 2614-3259

DOI : https://doi.org/10.36778/jesya.v5i1.680

\begin{tabular}{|l|r|r|r|r|r|}
\hline CS & 2084 & 2 & 22 & 4.31 & 1.891 \\
\hline FS (dalam miliaran Rupiah) & 2084 & 7 & 1296898 & 21692.22 & 89459.006 \\
\hline LEV & 2084 & .000320 & 19.511328 & .59981369 & .850876585 \\
\hline Valid N (listwise) & 2084 & & & & \\
\hline
\end{tabular}

Variabel dependen corporate social responsibility disclosure diukur dengan proksi indeks corporate social responsibility berbasis ISO 26000. Corporate social responsibility maksimum sebesar 0,918919 diwakili oleh Bank Tabungan Negara (Persero) Tbk, sedangkan minimum 0,027027 diwakili oleh Mahaka Media Tbk dengan mean 0,385485. Dari tabel diatas menunjukkan bahwa corporate social responsibility disclosure masih tergolong rendah dengan rata-rata hanya sebesar 38,55\% yang diungkapkan oleh perusahaan dari 37 indikator pengungkapan. Kesimpulannya bahwa beberapa entitas yang terdaftar di BEI masih belum mematuhi peraturan pemerintah yang mengatur tentang Perseroan Terbatas pada pasal 66 ayat 2c tahun 2007.

Semakin besar nilai DACC suatu entitas berarti bahwa semakin besar praktik manajemen laba dilakukan. DACC maksimum menunjukkan angka 5,092217 diwakili oleh Steady Safe Tbk, sedangkan nilai minimum sebesar -0,893539 diwakili oleh Trikomsel Oke Tbk dengan mean 0,129757. Rata-rata DACC sebesar 12,98\% yang menunjukkan masih adanya praktik ini pada perusahaan Indonesia.

ETR minimum sebesar -43,983634 (Metro Realty Tbk) dan maksimum dengan angka 21,575401 (Perdana Karya Perkasa Tbk). Mean ETR sebesar 21,96\% menunjukkan rata-rata instansi publik di Indonesia mempunyai tarif pajak sebenarnya di nilai $21,96 \%$ dari pajak atas profit yang dihasilkan suatu entitas. Dari penelitian ini dapat disimpulkan bahwa terdapat instansi di Indonesia masih melakukan praktik penghindaran pajak.

Statistik deskriptif minimum daripada kepemilikan manajerial yakni 0,00\%, menandakan bahwa di dalam perusahaan Indonesia masih terdapat dewan direksi yang tidak memegang saham diperusahaan. Nilai tertinggi daripada kepemilikan manajerial yakni 95,61\% diwakili oleh J Resources Asia Pasifik Tbk. Mean sebesar 3,74\% yang menandakan bahwa rata-rata instansi yang terdaftar di BEI sebagian kecil sahamnya dipegang oleh manajemen perusahaan.

Variabel kepemilikan institusional terendah adalah $0,00 \%$ dan tertinggi adalah sebesar 99,99\% (PT Bank JTrust Indonesia Tbk) dengan mean sebesar 63,48\%, yang menandakan institusi memiliki fungsi kontrol yang signifikan terhadap suatu instansi dibandingkan dengan pemegang saham lainnya. Kepemilikan asing maksimum sebesar 99,77\% diwakili oleh Bentoel International Investama Tbk. Sedangkan minimum dengan nilai $0,00 \%$ dan nilai mean sebesar $23,60 \%$ yang menandakan bahwa instansi di Indonesia masih terdapat saham yang dipegang oleh perusahaan asing, warga asing maupun instansi asing lainnya. Kesimpulannya bahwa yang mendominasi struktur kepemilikan pada perusahaan yang terdaftar di BEI adalah kepemilikan institusional dibandingkan dengan kepemilikan manajerial dan juga kepemilikan asing.

Variabel ukuran direksi dengan nilai terendah sebanyak 2 orang, sedangkan nilai tertinggi sebanyak 15 orang dengan mean sebanyak 5 orang. Variabel ukuran komisaris menunjukkan nilai minimum sebesar 2 orang, nilai maximum sebesar 22 orang dengan mean yakni 4 orang. Pada variabel ukuran direksi dan komisaris seluruh perusahaan yang terdaftar di BEI dalam penelitian ini, telah memenuhi ketentuan minimum jumlah anggota dewan direksi dalam Peraturan OJK No. 33/POJK.04/2014 mengenai Direksi dan Dewan Komisaris Emiten atau Perusahaan Publik, yaitu 2 orang anggota. 
Dari hasil uji diatas, masih adanya beberapa perusahaan yang belum memiliki anggota dewan direksi independen atau tidak mencantumkan informasi mengenai independensi tersebut pada laporan keuangan yang dilaporkan, hal ini ditunjukkan pada nilai minimum sebesar $0,00 \%$ variabel independensi dewan direksi. Sedangkan nilai maksimum menunjukkan angka sebesar 66,67\% (First Media Tbk), rata-rata perusahaan di BEI hanya memiliki 17,04\% anggota dewan direksi yang independen.

Variabel kontrol ukuran perusahaan minimum sebesar 7 miliar Rupiah (PT Rimo International Lestari Tbk), maksimum sebesar 1.296.898 miliar Rupiah (PT Bank Rakyat Indonesia (Persero) Tbk). Sedangkan mean ukuran perusahaan pada BEI sebesar 21692.22 miliar Rupiah. Nilai variabel kontrol leverage menerangkan bahwa rata-rata $60 \%$ kekayaan perusahaan publik Indonesia dibiayai oleh utang. Tingkat utang tertinggi tercatat pada tahun 2018 oleh Trikomsel Oke Tbk sedangkan PT Indoritel Makmur Internasional Tbk pada tahun 2014 memiliki nilai utang yang terkecil yaitu 0,032\%.

Tabel 3 Hasil Uji Hipotesis

\begin{tabular}{|l|r|r|l|l|}
\hline \multicolumn{1}{|c|}{ Variable } & \multicolumn{1}{c|}{ Coefficient } & \multicolumn{1}{c|}{ Sig. } & \multicolumn{1}{c|}{ Kesimpulan } & \multicolumn{1}{c|}{ Hipotesis } \\
\hline C & -1.387644 & 0.0000 & & \\
\hline DACC & -0.003029 & 0.8177 & Insig. & Tidak Terbukti \\
\hline ETR & -0.000834 & 0.5349 & Insig. & Tidak Terbukti \\
\hline MO & -0.015441 & 0.7516 Insig. & Tidak Terbukti \\
\hline IO & -0.005283 & 0.8574 & Insig. & Tidak Terbukti \\
\hline FO & -0.066663 & 0.0089 & Sig. - & Tidak Terbukti \\
\hline BOARD SIZE & 0.001534 & 0.6806 Insig. & Tidak Terbukti \\
\hline BOARD INDP & 0.107464 & 0.0025 & Sig.+ & Terbukti \\
\hline KOMISARIS & 0.002778 & 0.4396 Insig. & Tidak Terbukti \\
\hline FIRM SIZE & 0.139064 & 0.0000 & Sig.+ & Terbukti \\
\hline LEVERAGE & 0.020392 & 0.0004 Sig.+ & Terbukti \\
\hline
\end{tabular}

Hasil pengujian pada Tabel 3 menunjukkan bahwa variabel manajemen laba memiliki nilai koefisien regresi sebesar $-0,003029$, dan nilai signifikansi sebesar 0,8177 dimana lebih besar dari nilai probabilitas 0,05 . Tingkat probabilitas variabel manajemen laba diatas 0,05 artinya bahwa manajemen laba tidak berpengaruh signifikan terhadap corporate social responsibility. Hal demikian tidak konsisten dengan penelitian yang pernah dilakukan oleh Pagano dan Volpin (2005), Chih et al. (2008), Prior et al. (2008), Gargouri et al. (2010), Jo Hoje dan Harjoto (2011), Desai dan Dharmapala (2012), Kim (2012), Scholtens dan Kang (2013), Muttakin dan Subramaniam (2015), Cho dan Chun (2016), Christensen (2016), Djuitaningsih dan Marsyah (2016), Gras-Gil et al. (2016), Martinez-Ferrero dan Frias-Aceituno (2016), Alsaadi et al. (2017), Garcia-Sanchez dan Garcia-Meca (2017).

Hasil ini tidak sesuai dengan hipotesis, namun konsisten dengan penelitian Sukarmi (2008), Kim (2012), Terzaghi (2012), Salewski dan Zulch (2014), Tumewu dan Rudiawarni (2014). Hal ini dikarenakan dalam perkembangannya masih terdapat pandangan yang berbeda terhadap praktik corporate social responsibility, terutama semenjak diberlakukan peraturan mengenai laporan tahunan suatu perusahaan harus memuat laporan pelaksanaan corporate social responsibility. Corporate social responsibility di Indonesia lebih dimanfaatkan untuk kegiatan promosi dan meningkatkan reputasi perusahaan, sehingga yang mendorong pelaksanaan corporate social 
responsibility bukan strategi pertahanan manajerial yang berkaitan dengan manajemen laba.

Tabel 3 menunjukkan bahwa faktor penghindaran pajak dengan nilai koefisien yakni -0,000834 dan nilai signifikansi sebesar 0,5349 yang lebih besar dari 0,05. Hal ini memperlihatkan bahwa tidak adanya pengaruh signifikan antara penghindaran pajak dengan corporate social responsibility. Hasil ini bertentangan dengan penelitian Schon (2008), Watson (2011), Huseynov dan Klamm (2012), Davis (2013), Lanis dan Richardson (2013), Zhang (2013), Oktaviana (2014), Octaviana dan Rohman (2014), Utari (2014), Elbaz (2015), Dharma dan Noviari (2017).

Konsisten dengan penelitian Hansen (2015), Villafuerte (2015). Hal ini bisa terjadi dikarenakan, perusahaan Indonesia banyak yang melakukan corporate social responsibility hanya karena desakan dari pemerintah dan para pemangku kepentingan yang menuntut untuk dilakukannya corporate social responsibility. Bukti penelitian ini bisa dilihat bahwa masih terdapat beberapa instansi melakukan pengungkapan corporate social responsibility tinggi, juga memiliki nilai penghindaran pajak yang tinggi. Begitu sebaliknya, perusahaan yang memiliki penghindaran pajak rendah namun tidak melakukan pengungkapan corporate social responsibility.

Hasil pengujian faktor kepemilikan manajerial menunjukkan nilai signifikansi 0,7516 dan koefisien -0,015441. Nilai probabilitias berada diatas 0,05 dapat disimpulkan bahwa kepemilikan manajerial tidak memiliki pengaruh signifikan terhadap corporate social responsibility. Hal demikian tidak sesuai dengan penelitian yang telah dilakukan sebelumnya oleh Gray (1988), Sembiring (2005), Rosmasita (2007), Oliveira dan Ferreira (2011), Dewi (2013), Eriandani (2013), Udayana (2013), Paramita dan Marsono (2014), Prakasa (2016), Rahayu (2016) serta Masyitah (2016).

Sedangkan, hasil tersebut konsisten dengan Huafang dan Jinguo (2007), Rustiarini (2008), Said (2009), Mulia (2010), Waryanto (2010), Badjuri (2011), Tamba (2011), Nur dan Priantinah (2012), Terzhagi (2012), Laksmitaningrum dan Purwanto (2013), Martua dan Nasir (2013), Djuitaningsih dan Marsyah (2016), Swandari (2016), Saputro (2019).

Hal ini dikarenakan instansi di Indonesia yang terdaftar di BEI memiliki saham manajerial yang relatif kecil sehingga belum terdapat keselarasan kepentingan antara pemilik dan manajer. Perusahaan di Indonesia masih dinilai melakukan pengungkapan corporate social responsibility ataupun praktik corporate social responsibility hanya dikarenakan oleh desakan dari pemerintah. Pelaksanaan corporate social responsibility di Indonesia juga dinilai dari seberapa besar kerusakan yang akan ditimbulkan dari kegiatan operasional perusahaan tersebut, baru ditetapkan suatu kebijakan corporate social responsibility yang akan dilaksanakan oleh para manajer.

Variabel kepemilikan institusional menunjukkan nilai signifikansi 0,8574 dan koefisien -0,005283. Hasil uji ini seiring dengan Fauzi et al. (2007), Mahoney (2007), Rahman (2007), Machmud dan Djaman (2008), Utami dan Rahmawati (2010), Nilasari (2011), Rahkmawati (2011), Eriandani (2013), Saraswati dan Hadiprajitno (2013), Tumewu dan Rudiawarni (2014), Djuitaningsih dan Marsyah (2016) yang menunjukkan bahwa kepemilikan institusional tidak berpengaruh terhadap corporate social responsibility disclosure.

Namun tidak konsisten dengan penelitian Anggraini (2006), Nofandrilla (2008), Saleh (2010), Yulia dan Melvie Paramitha (2011), Sari (2013), Sukoharsono (2013), Sutrisno (2013), Soliman (2013), Udayana (2013), Saputro (2019). Tidak adanya korelasi ini disebabkan, institusi yang berinvestasi pada modal saham perusahaan Indonesia tidak 
terlalu memperhatikan permasalahan pengungkapan corporate social responsibility sebagai kriteria dalam melakukan investasi. Hal ini menyebabkan kurangnya motivasi instansi untuk melakukan pengungkapan corporate social responsibility tersebut.

Berdasarkan hasil uji hipotesis pada Tabel 3, variabel kepemilikan asing memiliki angka koefisien sebesar -0,066663 dan signifikansi 0,0089. Artinya bahwa variabel kepemilikan asing berpengaruh signifikan negatif terhadap corporate social responsibility. Hasil penelitian ini kontras dengan penelitian yang dilakukan oleh Chang (2003), Chapple dan Moon (2005), Tanimoto dan Suzuki (2005), Marwata (2006), Kim (2007), Djakman (2008), Machmud (2008), Darus (2009), Puspitasari (2009), Said (2009), Anggraini (2010), Saleh (2010), Oh (2011), Tamba (2011), Diba (2012), Amelia (2013), Khan dan Muttakin (2013), Soliman (2013), Sufian dan Zahan (2013), Sissandhy (2014), Dewi (2015), Isa dan Muhammad (2015). Temuan pada penelitian ini selaras dengan Zulvina, Fitri, Desi, Yani dan Makhdalena (2017), yang mana hasilnya menunjukkan bahwa kepemilikan asing berkorelasi negatif.

Secara umum instansi Indonesia yang dimiliki oleh kepemilikan asing tidak akan mempedulikan kondisi permasalahan lingkungan, sumber daya manusia ataupun kerusakan yang ditimbulkan dari operasional perusahaan yang ada di Indonesia, namun dorongan dalam pelaksanaan pengungkapan corporate social responsibility dalam laporan tahunan perusahaan yang dimiliki oleh kepemilikan asing hanya dilakukan karena adanya peraturan UU, berbeda dengan instansi yang dimiliki oleh kepemilikan lokal yang akan lebih mempedulikan akan kondisi Indonesia.

Variabel ukuran dewan direksi memiliki nilai koefisien sebesar 0,001534 dan signifikansi 0,6806, berarti bahwa ukuran dewan direksi tidak mempengaruhi corporate social responsibility. Hasil penelitian ini tidak sejalan dengan Prastiwi (2011), Suryono (2011), Esa dan Ghazali (2012), Pebriana (2012), Ali dan Atan (2013), Abdelkader (2016). Namun, selaras dengan penelitian Intan (2016) dan Sadou (2017). Hal ini disebabkan ukuran dewan direksi perusahaan yang merupakan perwakilan pihak manajemen yang memiliki otoritas tertinggi, akan lebih berusaha untuk mencapai apa yang diharapkan para pemegang saham dibandingkan melaksanakan apa yang diharapkan dari pemangku kepentingan lainnya. Dewan direksi lebih memilih mengubah kinerja keuangan perusahaan menjadi lebih baik daripada memperhatikan pelaksanaan praktik corporate social responsibility.

Berdasarkan hasil uji t pada Tabel 3, variabel direktur independen menunjukkan bahwa koefisien sebesar 0,107464 dan signifikansi 0,0025. Tingkat probabilitas variabel direktur independen dibawah 0,05 artinya bahwa variabel ini berpengaruh signifikan positif terhadap corporate social responsibility. Temuan ini selaras dengan penelitian Rouf (2010), Harjoto dan Jo (2011), Arfiur (2012), Muttakin dan Subramaniam (2015), Dias et al. (2017), Naseem (2017), Sadou (2017). Tetapi, tidak sejalan dengan Rahman dan Widyasari (2008), Saravanan (2009), Martin (2012), Rahman dan Ismail (2016).

Hal ini disebabkan oleh kehadiran direksi independen dipercaya sebagai mekanisme tata kelola perusahaan utama. Secara umum diyakini bahwa direktur luar yang independen akan memperkuat pemantauan terhadap kegiatan manajemen, kepentingan para investor terlindungi dan mencapai harapan para pemangku kepentingan terhadap perusahaan. Berdasarkan teori keagenan, direktur independen yang tidak berurutan dapat mendorong perusahaan untuk bertanggung jawab secara sosial untuk menghadapi perubahan peraturan dan krisis perusahaan (Petra, 2005).

Hasil uji pada Tabel 3 memperlihatkan bahwa variabel ukuran dewan komisaris dengan nilai koefisien sebesar 0,002778 dan signifikansi 0,4396. Hal ini berarti bahwa 
ukuran dewan komisaris tidak berpengaruh signifikan terhadap corporate social responsibility disclosure. Temuan penelitian ini konsisten dengan Ahmad (2003), Matoussi (2008), Chakroun (2008), Handajani (2009), Said (2009), Fahrizqi (2010), Waryanto (2010), Effendi (2012), Udayana (2013), Komalasari (2014), Sari (2014), Djuitaningsih dan Marsyah (2016).

Namun penelitian ini tidak konsisten dengan Coller dan Gregory (1999), Muntoro (2006), Sembiring (2005), Sulastini (2007), Andayani (2008), Sitepu dan Siregar (2008), Dewi (2013), Amalia (2013), Laksmitaningrum dan Purwanto (2013). Hal ini dikarenakan, dewan komisaris yang bertindak sebagai wakil dari pemegang saham lebih mengutamakan kepentingan pemegang saham dan meningkatkan keuntungan bagi para pemegang saham dibandingkan memikirkan pelaksanaan corporate social responsibility. Dewan komisaris juga lebih memilih menggunakan laba operasional untuk investasi kedepan yang lebih menguntungkan dibandingkan melakukan kegiatan corporate social responsibility. Hal lain juga dikarenakan Ketentuan di Indonesia dalam UU No. 40 tahun 2007 yang mewajibkan Perusahaan Tbk minimal memiliki dua orang anggota dewan komisaris.

\section{KESIMPULAN}

Berdasarkan hasil pengujian yang telah diuraikan pada Bab IV, penelitian ini bertujuan untuk memberikan hasil bukti empiris pengaruh variabel independen dan variabel kontrol terhadap variabel dependen yang digunakan pada penelitian ini. Berdasarkan hasil analisis yang diperoleh dalam menguji sampel sebagian perusahaan pada tahun 2014 hingga 2018 yang terdaftar di BEI berupa direktur independen, ukuran perusahaan dan leverage berpengaruh signifikan positif terhadap CSR disclosure, sedangkan manajemen laba, penghindaran pajak, kepemilikan manajerial, kepemilikan institusional, kepemilikan asing, ukuran dewan direksi, ukuran dewan komisaris masingmasing tidak berpengaruh signifikan terhadap CSR disclosure.

\section{DAFTAR PUSTAKA}

Al-Ajmi, M., Al-Mutairi, A., \& Al-Duwaila, N. (2015). Corporate social disclosure practices in Kuwait. International Journal of Economics and Finance, 7(9), 244.

Alkababji, M. W. (2014). Voluntary disclosure on corporate social responsibility: a study on the annual reports of Palestinian Corporations. European Journal of Accounting Auditing and Finance Research, 2(4), 59-82.

Amalia, D. (2014). Pengaruh Karakteristik Perusahaan Terhadap Corporate Social Responsibility Disclosure di Bursa Efek Indonesia. Media Riset Akuntansi, 3(1), Hal-34.

Appuhami, R., \& Tashakor, S. (2017). The Impact of Audit Committee Characteristics on CSR Disclosure: An Analysis of Australian Firms. Australian Accounting Review, 27(4), 400-420.

Chek, I. T., Mohamad, Z. Z., Yunus, J., \& Norwani, N. M. (2013). Corporate social responsibility (CSR) disclosure in consumer products and plantation industry in Malaysia. American International Journal of Contemporary Research, 3(5), 118 125.

Dias, A., Rodrigues, L. L., \& Craig, R. (2017). Corporate governance effects on social responsibility disclosures. Australasian Accounting Business and Finance Journal, 11(2).

Djuitaningsih, T., \& Marsyah, W. A. (2013). Pengaruh Manajemen Laba dan Mekanisme 
Corporate Governance Terhadap Corporate Social Responsibility Disclosure. Media Riset Akuntansi, 2(2).

Ebiringa, O. T., Yadirichukwu, E., Chigbu, E. E., \& Ogochukwu, O. J. (2013). Effect of firm size and profitability on corporate social disclosures: The Nigerian Oil and Gas sector in Focus. British Journal of Economics, Management \& Trade, 3(4), 563-574.

Esa, E., \& Anum Mohd Ghazali, N. (2012). Corporate social responsibility and corporate governance in Malaysian government-linked companies. Corporate Governance: The international journal of business in society, 12(3), 292-305.

Huang, H., \& Zhao, Z. (2016). The influence of political connection on corporate social responsibility_evidence from Listed private companies in China. International Journal of Corporate Social Responsibility, 1(1), 9.

Jia, M., \& Zhang, Z. (2013). Managerial Ownership and Corporate Social Performance: Evidence from Privately Owned Chinese Firms' Response to the Sichuan Earthquake. Corporate Social Responsibility and Environmental Management, 20(5), 257-274.

Juhmani, O. (2014). Determinants of corporate social and environmental disclosure on websites: The case of Bahrain. Universal Journal of Accounting and Finance, 2(4), 77-87.

Khan, A., Muttakin, M. B., \& Siddiqui, J. (2013). Corporate governance and corporate social responsibility disclosures: Evidence from an emerging economy. Journal of business ethics, 114(2), 207-223.

Laksmitaningrum, C. F., \& Purwanto, A. (2013). Analisis Pengaruh Karakteristik Perusahaan, Ukuran Dewan Komisaris dan Struktur Kepemilikan Terhadap Pengungkapan CSR (Studi Empiris pada Perusahaan Manufaktur Yang Terdaftar Di Bursa Efek Indonesia Tahun 2009-2011) (Doctoral dissertation, Fakultas Ekonomika dan Bisnis).

Landry, S., Deslandes, M., \& Fortin, A. (2013). Tax Aggressiveness, Corporate Social Responsibility, and Ownership Structure. Journal of Accounting, Ethics \& Public Policy, 14(3), 611-645.

Lanis, R., \& Richardson, G. (2012). Corporate Social Responsibility and Tax Aggressiveness : An Empirical Analysis. Journal of Accounting and Public Policy, 31(1), 86-108.

Lanis, R., \& Richardson, G. (2013). Corporate Social Responsibility and Tax Aggressiveness: A Test of Legitimacy Theory. Accounting, Auditing \& Accountability Journal, 26(1), 75-100.

Masyitah, E. (2017). Faktor-Faktor Yang Mempengaruhi Pengungkapan Sosial (Social Disclosure) Dalam Laporan Keuangan Tahunan Perusahaan Manufaktur Yang Terdaftar Di Bursa Efek Indonesia. Jurnal Al-Qasd Islamic Economic Alternative, $1(1), 52-70$.

Mulyadi, M. S., \& Anwar, Y. (2012). Influence of corporate governance and profitability to corporate CSR disclosure. International Journal of Arts and Commerce, 1(7), 29-35.

Muttakin, M. B., Khan, A., \& Subramaniam, N. (2015). Firm characteristics, board diversity and corporate social responsibility: evidence from Bangladesh. Pacific Accounting Review, 27(3), 353-372.

Muttakin, M. B., \& Subramaniam, N. (2015). Firm ownership and board characteristics: do they matter for corporate social responsibility disclosure of Indian companies?. 
Sustainability Accounting, Management and Policy Journal, 6(2), 138-165.

Naseem, M. A., Rehman, R. U., Ikram, A., \& Malik, F. (2017). Impact of board characteristics on corporate social responsibility disclosure. Journal of Applied Business Research, 33(4), 801.

Naser, K., \& Hassan, Y. (2013). Determinants of corporate social responsibility reporting: evidence from an emerging economy.

Octaviana, N. E., \& Rohman, A. (2014). Pengaruh Agresivitas Pajak Terhadap Corporate Social Responsibility: Untuk Menguji Teori Legistimasi (Studi Empiris Pada Perusahaan Pertambangan Dan Properti Yang Terdaftar Di Bursa Efek Indonesia Tahun 2009-2012) (Doctoral dissertation, Fakultas Ekonomika dan Bisnis).

Pradana, F. A., \& Suzan, L. (2016). Pengaruh Struktur Kepemilikan, Ukuran Perusahaan, Dan Umur Perusahaan Terhadap Pengungkapan Corporate Social Responsibility (csr)(studi Empiris Pada Perusahaan Manufaktur Yang Terdaftar Dalam Bursa Efek Indonesia Periode 2011-2014). eProceedings of Management, 3(1).

Rahayu, M. P., \& Darmawan, J. (2017, November). Pengaruh Agresivitas Pajak Terhadap Corporate Social Responsibility. In Prosiding Seminar Nasional Darmajaya (Vol. 1, No. 1, pp. 541-558).

Rahman, I. M. A., \& Ismail, K. N. I. K. (2016). The effects of political connection on corporate social responsibility disclosure-evidence from listed companies in Malaysia.

Ramdhaningsih, A. (2013). Pengaruh indikator good corporate governance dan profitabilitas pada pengungkapan corporate social responsibility. E-Jurnal Akuntansi, 368-386.

Ratnasari, N., \& Meita, I. (2017). Pengaruh Karakteristik Perusahaan Terhadap Pengungkapan Tanggung Jawab Sosial Dengan Kepemilikan Institusional Sebagai Variabel Moderasi. Jurnal Riset Manajemen dan Bisnis (JRMB) Fakultas Ekonomi UNIAT, 2, 201-214.

Rouf, D. (2011). The corporate social responsibility disclosure: A study of listed companies in Bangladesh.

Sadou, A., Alom, F., \& Laluddin, H. (2017). Corporate social responsibility disclosures in Malaysia: evidence from large companies. Social Responsibility Journal, 13(1), 177-202.

Setyarini, Y., \& Paramitha, M. (2011). Pengaruh Mekanisme Good Corporate Governance terhadap Corporate Social Responsibility. Jurnal kewirausahaan, 5(2), 10-17.

Uwuigbe, O. R. (2011). An empirical investigation of the association between firms' characteristics and corporate social disclosures in the Nigerian financial sector. Journal of Sustainable Development in Africa, 13(1), 60-74.

Uwuigbe, U., \& Egbide, B. C. (2012). Corporate Social Responsibility Disclosures in Nigeria: A Study of Listed Financial and Non-Financial Firms. J. Mgmt. \& Sustainability, 2, 160. 